\title{
MINIATURE IN EVERYTHING BUT MEANING: A CONTEXTUAL ANALYSIS OF MINIATURE VESSELS AT HOMOL'OVI I - ERRATUM
}

\author{
Samantha G. Fladd and Claire S. Barker
}

Doi: 10.1017/aaq.2018.79, Published on behalf of the Society for American Archaeology by Cambridge University Press, 17 December 2018

In the original publication of this article (Fladd and Barker 2018), Figure 2 was published without obtaining permission, due to an oversight. The article has since been corrected and Figure 2 replaced with a new version.

The publisher apologizes for the error.

\section{Reference Cited}

Fladd, Samantha G., and Claire S. Barker 2018 Miniature in Everything but Meaning: A Contextual Analysis of Miniature Vessels at Homol'ovi I. American Antiquity 84(1): 107-126. 